
\title{
$\begin{array}{ll}\text { Research Square } & \text { Preprints are preliminary reports that have not undergone peer review. } \\ \text { They should not be considered conclusive, used to inform clinical practice, } \\ \text { or referenced by the media as validated information. }\end{array}$
}

\section{Simultaneous Biodegradation of Harmful Cylindrospermopsis Raciborskii and Cylindrospermopsin Toxin in Batch Culture by Single Bacillus Strain}

\section{Zakaria Mohamed ( $\nabla$ mzakaria_99@yahoo.com )}

Sohag University Faculty of Science https://orcid.org/0000-0001-6378-1914

\section{Saad Alamri}

King Khalid University, Faculty of Science, Biological Science Department, P.O. Box 10255, Abha 61321, Saudi Arabia. Assiut University, Faculty of Science, Botany and Microbiology Department, Assiut 71516, Egypt

\section{Mohamed Hashem}

King Khalid University, Faculty of Science, Biological Science Department, P.O. Box 10255, Abha 61321, Saudi Arabia. Research Center for Advanced Materials Science (RCAMS), King Khalid University, Abha 61413, P.O. Box 9004, Saudi Arabia

\section{Research}

Keywords: Bacteria, biodegradation, biological control, Cylindrospermopsis, cylindrospermopsin, lysis

Posted Date: December 11th, 2020

DOI: https://doi.org/10.21203/rs.3.rs-125002/v1

License: (c) (i) This work is licensed under a Creative Commons Attribution 4.0 International License. Read Full License

Version of Record: A version of this preprint was published at Environmental Science and Pollution Research on August 21st, 2021. See the published version at https://doi.org/10.1007/s11356-021-16062Z. 


\section{Abstract}

This study investigates the capability of a Bacillus flexus strain isolated from decayed cyanobacterial blooms for the bioremediation of Cylindrospermopsis raciborskii and cylindrospermopsin (CYN) toxin. The algicidal activity of this strain was tested by co-cultivation with $C$. raciborskii cultures. CYN biodegradation was investigated in the presence of living and heat-inactivated bacterial cells or bacterial filtrate. Living bacterial cells inhibited $C$. raciborskii growth after 2 days of incubation with complete cell death at day 5. Bacterial filtrate caused a rapid reduction in $C$. raciborskii growth at the first day, with complete cell lysis at day3. Only living cells of SSZ01 caused reduction in CYN released into the medium during the bacterial decay of $C$. raciborskii cells. The biodegradation rate of CYN by SSZ01 relied on initial toxin concentrations. The highest rate $\left(42 \mu \mathrm{g} \mathrm{CYN} \mathrm{L}^{-1} \mathrm{day}^{-1}\right)$ was obtained at the higher initial concentration $\left(300 \mu \mathrm{g} \mathrm{L}^{-1}\right)$, and the lowest $\left(4 \mu \mathrm{g} \mathrm{CYN} \mathrm{L}^{-1}\right.$ day $\left.^{-1}\right)$ was at lower concentration $\left(50 \mu \mathrm{g} \mathrm{L}^{-1}\right)$. These results suggest that this bacterial strain could be employed to bioremediate cyanobacterial blooms in freshwaters. Also, the application of this bacterium in slow sand filters would give possibilities for degradation and bioremediation of cyanotoxins in drinking water treatment plants.

\section{Introduction}

Harmful cyanobacterial blooms (HCBs) seriously threaten the environmental and human health. HCBs are a common phenomenon in freshwater environments worldwide, and they may increase in the future because of progressive eutrophication of aquatic ecosystems and climate change (Paerl and Otten 2013). Most cyanobacterial blooms are constituted by toxin-producing species which damage the aquatic ecosystem and impair the safety of drinking water (Mohamed et al.2015). Among bloomforming cyanobacteria, $C$. raciborskii is one of the most common and widespread species, and characterized by geographic expansion due to its high plasticity and physiological tolerance to a wide range of environmental conditions, e.g. light, temperature and nutrients (Padisák 1997; Burford et al. 2016). Additionally, C. raciborskii can produce hepatoxins (e.g. cylindrospermopsin) and neurotoxins (saxitoxins) that have been implicated in fish, domestic livestock, and human mortalities (Svircev et al. 2016).

CYN is an alkaloid toxin with a low molecular weight (415Da), inhibiting protein synthesis (Van Apeldoorn et al. 2007) and inducing genotoxicity and carcinogenicity (Bazin et al. 2010). Compared to other cyanotoxins, CYN occurs extracellularly with large amounts (up to 98\%) due to its high water solubility and apparent membrane permeability (Rücker et al. 2007; Wormer et al. 2008). The toxin exhibits a high persistent in different water environments because of its chemical stability and slow degradation (Wormer et al. 2008). This trait is of a particular concern for water authorities for controlling Cylindrospermopsis growth and removing CYN toxin from drinking and irrigation waters.

Generally, cyanobateria and cyanotoxins can be removed from water by physical methods (e.g. clay and ultrasonication), chemical methods (chemical substances), and biological methods using algicidal microorganisms (Shao et al. 2013). However, physical and chemicals methods have significant 
disadvantages, where physical methods are not comprehensive and high energy cost and chemical methods can cause secondary pollution leading to the collapse of aquatic environments (Nishu et al. 2019). Biological methods, on the other hand, are relatively cost effective with low risk and could be considered a promising approach for bioremediation of cyanobacterial blooms in water sources (Hou et al. 2019).

Cyanobacterial blooms contain associated microorganisms including viruses, bacteria and fungi (Mohamed et al. 2018). Some of these microorganisms exhibit strong antagonistic effects on these blooms (Li et al. 2011; Van Wichelen et al. 2016), and thereby they could be exploited in bio-controlling and bioremediation of harmful cyanobacteria in water bodies. Numerous studies have been made on anti-cyanobacterial activity of heterotrophic bacteria and their degrading capabilities of cyanotoxins (Ndlela et al. 2018; Nishu et al. 2019; Weiss et al. 2019; Massey and Yang 2020). However, most of these studies have concentrated mainly on one cyanobacterial species ( $M$. aeruginosa) and one cyanotoxin type (microcystin). Although Cylindrospermopsis is as common as Microcystis in the aquatic environments (Wörmer et al. 2010), little is known about growth inhibition of C. raciborskii and CYN biodegradation by bacteria (Mohamed and Alamri 2012; Dziga et al. 2016). Previously, our research team isolated the bacterium Bacillus flexus SSZ01 strain from decayed cyanobacterial blooms in a Saudi eutrophic lake, and found that this strain could effectively degrade MC-RR (Alamri 2012). As C. raciborskii has been among the species constituted cyanobacterial blooms from which $B$. flexus was isolated, this bacterial strain may have antagonistic effect on this cyanobacterium and its $\mathrm{CYN}$ toxin. Therefore, the aim of this study was to investigate the potential growth inhibition of $B$. flexus SSZ01 strain against $C$. raciborskii, and to evaluate its capability of degrading CYN toxin produced by this cyanobacterium.

\section{Materials And Methods}

\section{Organisms}

The bacterial strain used in experiments was previously isolated from decayed cyanobacterial blooms in Saudi eutrophic lake, identified as Bacillus flexus based on 16S rRNA gene analysis, and assigned as SSZ01 strain (accession number GU112451) (Alamri 2012). The strain has also been reported as a microcystin degrader (Alamri 2012). The strain was inoculated into a 250-ml sterile conical flask containing $100 \mathrm{~mL}$ of sterile nutrient Broth (NB), and incubated in a shaking incubator $(150 \mathrm{rpm})$ at $30^{\circ} \mathrm{C}$ for $48 \mathrm{~h}$. The cell- free supernatant (bacterial filtrate) of the SSZ01 culture was then separated from bacterial cells by centrifugation at 15,000 rpm for $10 \mathrm{~min}$. The pellets were washed twice and resuspended in sterilized water to the required concentration of bacterial cells. Both bacterial suspension and filtrate were used immediately in the experiments of bacterial algicidal activity. C. raciborskii strain used in this study was previously isolated from cyanobacterial blooms in a Saudi dam lake, and found to produce CYN at a concentration of $568 \mu \mathrm{g} \mathrm{g}^{-1}$ (Mohamed and Al-Shehri 2013). The strain was grown in BG-11 medium without nitrogen at $25^{\circ} \mathrm{C}$ and continuous illumination at approximately $90 \mu \mathrm{mol}$ photons $\mathrm{m}^{-2} \mathrm{~s}^{-1}$. The axenity of this strain was achieved by using a mixture antibiotics (rifampicin $-300 \mathrm{mg} \mathrm{L}^{-1}$, streptomycin/penicillin $\left.-25 \mathrm{mg} \mathrm{L}^{-1}\right)$ and antifungal nystatin $\left(10 \mathrm{mg} \mathrm{L}^{-1}\right)$ (Wilkens and Maas 2012). The 
cells of axenic culture of $C$. raciborskii were then used in the experiments of bacterial algicidal activity. Exponentially growing cells of this strain were transferred into a $250 \mathrm{~mL}$ flask containing $100 \mathrm{~mL} \mathrm{BG}-11$ medium without nitrogen to give an initial cell density of $3.9 \times 10^{5}$ cells $\mathrm{mL}^{-1}$.

\section{Algicidal activity of bacterial strain SSZ01}

The direct and indirect algicidal modes of bacterial strain SSZ01 were determined by inoculation of bacterial cells or cell-free filtrate into $C$. raciborskii cultures, respectively.

Bacterial suspension of SSZ01cells at a final concentration of $10^{7} \mathrm{cfu} \mathrm{ml}^{-1}$ or bacterial filtrate $(10 \mathrm{ml})$ was added into a $250-\mathrm{ml}$ sterile conical flask containing $100 \mathrm{~mL}$ of $C$. raciborskii in the exponentialgrowth phase $\left(3.9 \times 10^{5}\right.$ cells $\left.\mathrm{ml}^{-1}\right)$. NB medium was not used in this experiment to test the ability of SSZ01 strain to lyse Cylindrospermopsis cells and use their constituents as a carbon source. Cylindropspermopsis cultures without bacteria or bacterial filtrate were used as a control. Bacterial cells of SSZ01 strain cultivated in BG11 medium served as negative procedural control. To study the effect of initial cell density of SSZ01 strain and the filtrate concentration on the algicidal activity, different concentrations of bacterial strain $\left(10^{3}, 10^{4}, 10^{5}\right.$, and $\left.10^{6} \mathrm{cfu} \mathrm{ml}^{-1}\right)$ or different proportions of bacterial filtrate $(10 \%, 25 \%$ and $50 \%)$ were added into a $250-\mathrm{ml}$ sterile conical flask containing exponentially growing $C$. raciborskii $\left(3.9 \times 10^{5}\right.$ cells $\left.\mathrm{ml}^{-1}\right)$. Both control and treated $C$. raciborskii cultures were incubated under the same growth conditions outlined above for 7 days. The cyanobacterial growth was measured daily by counting $C$. raciborskii cells using a Sedgewick-Rafter counting chamber undera compound microscope. The algicidal activity was expressed as the decrease in cell count of $C$. raciborskii in treated cultures compared to control. At the same time, the growth of SSZ01 strain in control and treated cultures was estimated by measuring the optical density (OD) spectrophotometrically at $600 \mathrm{~nm}$ wavelength. All samples were taken from cultures under aseptic conditions. All the experiments were conducted in triplicate.

\section{Cylindrospermopsin degradation by bacterial strain SSZ01}

To test the capability of the bacterial strain SSZ01 for degrading CYN released into the medium of bacterial-cyanobacterial cultures, an aliquot was taken daily from bacteria-treated and filtrate-treated Cylindrospermopsis cultures. The samples were centrifuged at $10000 \mathrm{xg}$ for $15 \mathrm{~min}$, and CYN concentration in the supernatant was determined by Enzyme-linked immunosorbent assay (ELISA) using commercial kits purchased from Abraxis (54 Steamwhistle Drive Warminster, PA 18974). To determine the effect of initial concentration of CYN on its biodegradation by SSZ01, the strain was inoculated into sterile $250 \mathrm{ml}$ Erlenmeyer flasks containing $100 \mathrm{ml}$ of sterilized BG-11 medium. Different concentrations of $\operatorname{CYN}\left(50,100,150,200,250\right.$ and $\left.300 \mu \mathrm{g} \mathrm{L}^{-1}\right)$ were then added separately to these flasks. Pure cylindrospermopsin toxin was purchased from Abraxis (Warminster, PA, USA). Flasks with sterilized BG11 and $100 \mu \mathrm{g} \mathrm{CYN} \mathrm{L}{ }^{-1}$, but without bacterial cells were used as control, to determine any losses of CYN due to factors other than biological degradation. To investigate the possible adsorption of CYN on bacterial cell walls, heat-inactivated bacterial cells of SSZ01 strain were added to a 250-ml conical flask 
containing BG-11 medium and $100 \mu \mathrm{g} \mathrm{CYN} \mathrm{L}^{-1}$. All biodegradation experiments of CYN by SSZ01 strain were conducted at $30^{\circ} \mathrm{C}$ and $\mathrm{pH} 8$, the optimal conditions reported earlier by many authors (Mohamed and Alamri 2012; Dziga et al. 2016). Both control and treated flasks were incubated in the dark with shaking (140 rpm) for 10 days. Subsamples $(1 \mathrm{ml})$ were withdrawn aseptically from the flasks at regular intervals for bacterial growth determination and CYN analysis. Residual CYN remaining in the solution was determined by ELISA, whereas bacterial growth was measured as optical density according to the methods described above. The average biodegradation rate was calculated by dividing the initial CYN concentration added into the flask at the beginning of the biodegradation experiment by the number of days until the toxin was no longer detected by ELISA. All experiments were run in triplicate.

\section{Statistical analysis}

All data obtained during the present study met the assumptions of ANOVA (independence, homogeneity of variance and normality). Variances in the cell density and CYN concentrations between control and treated cultures were estimated by one-way repeated-measures analysis of variance (ANOVA) followed by Tukey's post-hoc test $(P<0.05)$.

\section{Results}

\section{Growth inhibition of C. racibosrkki by SSZ01}

The bacterial strain SSZ01 showed algicidal activity towards the cyanobacterium $C$. raciborskii, and reduced its growth significantly $(\mathrm{P}<0.05)$ compared to control (Fig. 1$)$. The cell density of $C$. raciborskii cocultivated with living bacterial cells increased in the first 2 days, and subsequently decreased and all cyanobacterial cells lysed by day 5 (Fig .1). This inhibitory effect on cyanobacterial growth increased with the increase of initial cell density of SSZ01. The strongest inhibition of cyanobacterial growth occurred at initial bacterial concentration of $10^{6}$, which caused complete cell lysis by day 5 , but the weakest inhibition occurred at initial concentration of $10^{3}$, which caused no complete death of cyanobacterial cells (Fig.2). The bacterial filtrate also reduced the cell density of $C$. raciborskii during the first day of incubation and all cells completely died by day 3 (Fig.1). The antialgal activity of the bacterial filtrate increased with the increase in the proportion of filtrate added to the cultures $(P<0.05)$ (Fig. 3). The $50 \%$ filtrate proportion caused complete growth inhibition of $C$. raciborskii by the fourth day of incubation, while the $25 \%$ filtrate proportion caused complete inhibition by day 7 . The $10 \%$ filtrate proportion reduced $C$. raciborskii growth slightly but without complete lysis of the cells (Fig. 3). Moreover, the inhibition of $C$. raciborskii growth by living bacterial cells and its filtrate varied with the incubation time $(P<0.05)$. The longer the incubation time is, the stronger the growth inhibition. The growth (estimated as optical density) of the bacterial strain SSZ01 co-incubated with $C$. raciborskii culture increased significantly $(P<0.05)$ compared with its growth in control culture grown in NB medium (Fig. 4).

The results of toxin analysis revealed an increase in CYN concentrations released into the medium of $C$. raciborskii cultures treated with either living bacterial cells or its filtrate compared to control cultures ( $P$ 
$<0.05$ ) (Fig. 5). CYN concentrations released into the medium of $C$. raciborskii cultures treated with living bacteria were higher than those detected in cultures treated with bacterial filtrate. The maximum levels of released $\mathrm{CYN}$ in cyanobacterial cultures treated with living bacterial cells were obtained on the fourth day of incubation, coinciding with the complete lysis of $C$. raciborskii cells (Fig. 2, 5). After that, the released CYN decreased sharply in the medium of $C$. raciborskii cultures treated with living bacteria and became undetectable at day 8 (Fig.5). Conversely, no significant change $(P<0.05)$ in the concentrations of CYN released into the medium of $C$. raciborskii cultures treated with bacterial filtrate was observed along the incubation period (Fig.5). CYN concentrations incubated with heat-inactivated bacterial cells did not significantly change along the experiment period (therefore data not shown), confirming that the decrease in $\mathrm{CYN}$ concentrations in our experiments was rather due to degradation by living bacteria than adsorption onto bacterial cell walls. The reduction in CYN concentrations by SSZ01strain varied significantly $(P<0.05)$ with the initial concentrations. The biodegradation rate increased proportionally $(P$ $<0.05$ ) to the initial CYN concentrations (Fig.6). The highest biodegradation rate ( $42 \mu \mathrm{g} \mathrm{CYN} \mathrm{L}^{-1}$ day $\left.^{-1}\right)$ observed at the highest initial concentration of CYN $\left(300 \mu \mathrm{g} \mathrm{L}^{-1}\right)$, while the lowest $\left(4 \mu \mathrm{g} \mathrm{CYN} \mathrm{L}^{-1} \mathrm{day}^{-1}\right)$ was obtained at the lowest initial concentration $\left(50 \mu \mathrm{g} \mathrm{L}^{-1}\right)$ (Fig. 6). Complete degradation of $\mathrm{CYN}$ by SSZ01strain also relied on the initial toxin concentration ( $r=0.98)$. The highest $C Y N$ concentration $(300 \mu \mathrm{g}$

$\mathrm{L}^{-1}$ ) was completely degraded in 7 days, whereas lower CYN concentrations $\left(50 \& 100 \mu \mathrm{g} \mathrm{L}^{-1}\right)$ took 13 and 11 days, respectively, to be completely degraded by this bacterium.

\section{Discussion}

Our study clearly demonstrates the ability of the bacterium Bacillus flexus SSZ01, isolated from decayed cyanobacterial blooms, to inhibit the growth of the cyanobacterium $C$. raciborskii and degrade its $C Y N$ toxin released into the medium. The results showed that the co-cultivation of $C$. raciborskii with bacterial cells resulted in the reduction of $C$. raciborskii cell density, with complete cell lysis within 5 days. The removal efficiency of $C$. raciborskii cells by our bacterial strain can be compared to that of the strongest algicidal bacteria reported in previous studies, such as Aeromonas and Bacillus, which completely removed and lysed cyanobacterial cells of M. aeruginosa and Oscillatroia planctonica from 5 to 6 days (Lee et al. 2018, Hu et al. 2019; Yang et al. 2020). For C. raciborskii, this is the first study investigating the algicidal and lytic activity of a bacterial strain against this toxic cyanobacterium. Generally, the mechanisms underlying the inhibitory and lysing activity of algicidal bacteria can be through direct physical contact between bacterial and cyanobacterial cells, or indirectly via excretion of extracellular chemicals or enzymes by bacteria into the surrounding medium (Luo et al. 2013; Lee et al. 2018, Hu et al. 2019). In this study, the filtrate of bacterial strain SSZ01 inhibited the growth of $C$. racibrskii during the first day of incubation, while the inhibition and lysis of $C$. raciborskii cells co-cultivated with SSZ01 cells commenced after 3 days of incubation. This indicates that the growth inhibition and cell lysis of $C$. raciborskii occurred through the secretion of extracellular active compounds by this bacterial strain, and this bacterium requires time to produce these active compounds and excrete them into the medium. This explains why the growth inhibition of $C$. raciborskii by bacterial filtrate occurred at the first day of incubation, as the filtrate contained large amounts of inhibitory substances produced by bacteria during 
long time. On the other hand, the growth inhibition of $C$. raciborskii by bacterial cells occurred after 3 days, the time required for bacteria to produce enough cyanobacteria-lysing substances. In this respect, Wang et al. (2020) hypothesized that the active substances of cyanobacteria-lysing substances produced by algcidal bacteria begin to accumulate in the lag phase and reach the maximum during the logarithmic growth phase. Thus, the inhibitory and lysing activity of bacterial strain SSZ01 against $C$. raciborskii was via the indirect mode, possibly involving active substances secreted by the bacteria rather than bacteria themselves. Consistent with our study, Lee et al. (2018) demonstrated that $M$. aeruginosa cells were killed via indirect attack through compounds secreted by Bacillus sp. The cyanobacteria-lysing effect of strains of algicidal bacteria, Raoultella planticola and Aeromonas sp. against $M$. aeruginosa also reflected this trend of algicidal mechanism (Yang et al. 2020). Similarly, Oscillatoria planctonica cells were lysed by extracellular products of Bacillus cereus CZBC1 (Hu et al. 2019). Most of these studies demonstrated that the lytic activity of algicidal bacteria are associating with initial cell density of bacteria (Hu et al. 2019; Yang et al. 2020). Concomitant with these studies, our results revealed that strain SSZ01 with initial cell density of $10^{6} \mathrm{cfu} \mathrm{ml}^{-1}$ exhibited strong and rapid aligicidal activity against $C$. raciborskii, but when its initial cell density was lower $\left(10^{3} \mathrm{cfu} \mathrm{ml}^{-1}\right)$, its inhibitory effects were weak with no complete death of cyanobacterial cells. Accordingly, Shao et al. (2014) found that Bacillus sp. B50 showed an algicidal activity at $1.9 \times 10^{6} \mathrm{cfu} \mathrm{ml}^{-1}$, with no algicidal effect observed at cell densities lower than $10^{5} \mathrm{cfu} \mathrm{ml}^{-1}$. More recently, Hu et al. (2019) reported that $B$. cereus CZBC1 exhibited alginolytic effects on $O$. planctonica at initial concentration of $10^{6} \mathrm{cfu} \mathrm{ml}^{-1}$, but this activity was weak and delayed by 5 days at lower initial concentration $\left(10^{3} \mathrm{cfu} \mathrm{ml}^{-1}\right)$.

In addition to growth inhibition and cell lysis of $C$. raciborskii, the bacterial strain SSZ01 was capable of reducing $\mathrm{CYN}$ toxin released into the medium after the decay of $C$. raciborskii cells. Interestingly, the reduction in released CYN has taken place in cyanobacterial cultures treated with living bacterial cells, but not in cultures treated with bacterial filtrate or heat-inactivated bacterial cells. It can be inferred from this finding that CYN could not be adsorbed onto bacterial cell walls, but was rather degraded via biodegradation metabolism and enzymatic activities of living bacterial cells, possibly using CYN toxin as a carbon and nitrogen source for its growth. This supports the results of earlier studies reporting that bacteria with previous history of CYN-producing cyanobacterial blooms or present in preconditioned sediments with CYN, can proliferate and degrade this toxin and use it as a carbon source (Klitzke et al. 2010; Mohamed and Alamri 2012; Dziga et al. 2016). Moreover, the complete CYN degradation by strain SSZ01 occurred more rapidly (7 days) at higher initial CYN concentration (300 $\left.\mu \mathrm{g} \mathrm{L}^{-1}\right)$ compared to 11-13 days at lower toxin concentrations ( $100 \& 50 \mathrm{\mu g} \mathrm{L}^{-1}$, respectively). Our results are in harmony with those obtained by Mohamed and Alamri (2012), who found that complete CYN degradation by Bacillus AMRI03 occurred after 6 days at initial toxin concentration of $300 \mu \mathrm{g} \mathrm{L}^{-1}$, and after 7 and 8 days at lower concentrations ( $100 \& 10 \mu \mathrm{g} \mathrm{L}^{-1}$. Earlier, Smith et al. (2008) also reported complete CYN degradation at initial concentrations of $13-76 \mu \mathrm{g} \mathrm{L}^{-1}$, but not observed at initial concentrations of 3-6.8 $\mu \mathrm{g} \mathrm{L}^{-1}$. Those authors hypothesized that CYN could act as an inducer activating the genes of enzymes responsible for the degradation of this toxin (Smith et al. 2008). Hence, the lack or slowness of complete CYN 
degradation by bacteria at low toxin concentrations may be due to that these concentrations are lower than the threshold CYN concentration required to induce toxin degradation genes (Smith et al. 2008, Mohamed and Alamri 2012). To evaluate the efficiency of SSZ01 strain for CYN decomposition, we measured biodegradation rate at different initial CYN concentrations. The results showed a strong positive correlation $\left(R^{2}=0.974\right)$ between the initial CYN concentration and the degradation rate of CYN (Fig.6).The highest the initial CYN concentration $\left(300 \mu \mathrm{g} \mathrm{L}^{-1}\right)$, the highest the degradation rate $\left(42 \mu \mathrm{g} \mathrm{L}^{-1}\right.$ day $\left.^{-1}\right)$, and the lowest the initial CYN concentration $\left(50 \mu \mathrm{g} \mathrm{L}^{-1}\right)$, the lowest the degradation rate $\left(4 \mu \mathrm{g} \mathrm{L}^{-1}\right.$ day $\left.^{-1}\right)$. Moreover, the degradation rates of CYN by our strain SSZ01 (4-42 $\mu \mathrm{g} \mathrm{L}^{-1}$ day $\left.^{-1}\right)$ can be compared to those obtained (1.25-50 $\mathrm{g} \mathrm{L} \mathrm{L}^{-1} \mathrm{day}^{-1}$ ) by Bacillus AMRI-03 (Mohamed and Alamri 2012). However, They are much lower than that of Aeromonas strain R6 (230-28 $\mathrm{g} \mathrm{L}^{-1}$ day $\left.^{-1}\right)$ exposed to initial CYN concentrations ranging from 10 to $20 \mathrm{mg} \mathrm{L}^{-1}$ (Dziga et al. 2016). This discrepancy could be due to the difference in initial CYN concentrations used in these studies, and due to the difference in bacterial strains involved in toxin biodegradation. Also, it is interesting to remark that SSZ01 strain was previously reported to be capable of MC degradation (Alamri 2012). This indicates that the hydrolytic enzymes in this strain have wide substrate specificity and can metabolize other compounds to be used as a carbon source. Concomitant with these results is that a Bacillus strain capable of MC degradation was also able to degrade CYN toxin (Mohamed and Alamri 2012). However, further studies are needed to characterize the enzymes and genes involved in the hydrolysis of CYN.

\section{Conclusions}

In this study, we examined the algicidal activity of a Bacillus strain isolated from decay cyanobacterial blooms against the toxic cyanobacterum $C$. racibosrkii. The bacterial strain displayed a strong lethal effect against $C$. racibosrkii, and this algicidal activity occurred through indirect attack mediated by active compounds excreted by this bacterium into the medium. This led to the lysis of cyanobacterial cells and the release of $\mathrm{CYN}$ toxin into the medium. The released CYN began to decrease at the third day of incubation with bacterial cells until became undetectable by day 8 . The results of batch experiment of incubation of SSZ01 strain with CYN toxin revealed the ability of this bacterial strain to degrade this toxin, with degradation rate increasing with the increase of initial CYN concentrations. We can infer from these results that the coexistence of such bacteria with CYN in the same environment can contribute to the self-purification and bioremediation of the ecosystem from such potent toxins. Additionally, these algicidal and toxin - degrading bacteria would have great potential application in controlling the cyanobacterial blooms in water sources and preventing a negative impact on human health. Additionally, since the biodegradation of cyanotoxins in water has been proven to be very effective by hetrotrophic bacteria with non-toxic degradation by-products (Tsuji et al. 2006), such toxin-degrading bacteria could be applied in slow sand filtration for degrading and removing cyanotoxins in drinking water treatment plants. However, prior to in-situ application, further studies on the potential effects of Bacillus SSZ01 strain on the entire aquatic ecosystem and water quality should be carried out in microcosm or mesocosm experiments. 


\section{Declarations}

Ethical Approval and Consent to Participate: Not applicable

Consent to Publish: Not applicable

Authors Contributions: $\mathrm{MH}$ and SA cultured the bacteria strain and followed its growth in biodegradation experiments. ZM collected and tabulated data of antialgal and toxin- degrading fungi. ZM set up the experiments of algicidal activity of bacteria and biodegradation of toxin in cyanobacterial cultures, and was a major contributor in writing the manuscript. All authors participated in analysis and interpretation of the data, read and approved the final manuscript.

Funding: the authors declare that funding received from the Research Center of Advanced Materials King Khalid University, Saudi Arabia, Grant \# RCAMS/KKU/003/20, was used in the design of the study and collection, analysis, and interpretation of data and in writing the manuscript.

Availability of data and materials: Not applicable

Acknowledgements: This study was supported by Research Center of Advanced Materials - King Khalid University, Saudi Arabia, Grant \# RCAMS/KKU/003/20.

Conflict of interest: The authors declare that there is no conflict of interest.

\section{Acknowledgements}

This study was supported by Research Center of Advanced Materials - King Khalid University, Saudi Arabia, Grant \# RCAMS/KKU/003/20.

\section{Conflict of interest}

The authors declare that there is no any kind of conflict of interest.

\section{References}

Alamri SA (2012) Biodegradation of microcystin-RR by Bacillus flexus isolated from a Saudi freshwater lake. Saud J Biol Sci 19: 435-440.

Bazin E, Mourot A, Humpage AR, Fessard V (2010) Genotoxicity of a freshwater cyanotoxin, cylindrospermopsin, in two human cell lines: Caco-2 and HepaRG. Environ Mol Mutagen 51: 251-259.

Burford MA, Davis TW (2011) Physical and chemical processes promoting dominance of the toxic cyanobacterium Cylindrospermopsis raciborskii. Chin J Oceanol Limnol 29: 883-891.

Dziga D, Kokocinski M, Maksylewicz A, Czaja-ProkopU , Barylski J (2016) Cylindrospermopsin Biodegradation Abilities of Aeromonas sp. Isolated from Rusałka Lake. Toxins 8: 55. 
Hou X, Huang J, Tang , Wang NA, Zhang LU, Gu L (2019) Allelopathic inhibition of juglone (5-hydroxy-1,4naphthoquinone) on the growth and physiological performance in Microcystis aeruginosa. $\mathrm{J}$ Environ Manage 232: 382-386.

Hu X, Xu Y, Su HC,2, Xu WJ, Wang LH, XuYN, Li ZJ, Yu-Cheng Cao YC, Wen GL (2019) Algicidal bacterium CZBC1 inhibits the growth of Oscillatoria chlorina, Oscillatoria tenuis, and Oscillatoria planctonica. AMB Expr 9:144.

Klitzke S, Apelt S, Weiler C, Fastner J, Chorus I (2010) Retention and degradation of the cyanobacterial toxin cylindrospermopsin in sediments - the role of sediment preconditioning and DOM composition. Toxicon 55: 999-1007.

Lee C, Jeon MS, Thi-Thao T, Park C, Jong-Soon Choi J, Kwon J, Roh SW, Yoon-E Choi YE (2018) Establishment of a new strategy against Microcystis bloom using newlyisolated lytic and toxin-degrading bacteria. J Appl Phycol 30: 1795-1806.

Li N, Zhang L, Li F, Wang Y, Zhu Y, Kang H (2011) Metagenome of microorganisms associated with the toxic cyanobacteria Microcystis aeruginosa analyzed using the 454 sequencing platform. Chinese $\mathrm{J}$ Oceanol Limnol 29: 505-513.

Luo JF, Wang Y, Tang SS, Liang JW, Lin WT, Luo LX (2013) Isolation and identification of algicidal compound from Streptomyces and algicidal mechanism to Microcystis aeruginosa. PLoS ONE 8:e76444.

Massey IY, Yang F (2020) A mini review on microcystins and bacteria degradation. Toxins 12:268.

Mohamed ZA, Alamri SA (2012) Biodegradation of cylindrospermopsin toxin by microcystin- degrading bacteria isolated from cyanobacterial blooms. Toxicon 60: 1390-1395.

Mohamed ZA, Al-Shehri AM (2013) Assessment of cylindrospermopsin toxin in an arid Saudi lake containing dense cyanobacterial bloom. Environ Monitor Assess 185:2157-2166.

Mohamed ZA, Bakr AA, Ghramh HA (2018) Grazing of the copepod Cyclops vicinus on toxic Microcystis aeruginosa: potential for controlling cyanobacterial blooms and transfer of toxins. Oceanol Hydrobiol Stud 47: 296-302.

Mohamed ZA, Deyab MA, Abou-Dobara MI, Kamel A, El-Raghi WM (2015) Occurrence of cyanobacteria and microcystin toxins in raw and treated waters of the Nile River, Egypt: Implication for water treatment and human health. Environ Sci Poll Res 22:11716-11727.

Ndlela LL, Oberholster PJ, Van Wyk JH, Cheng PH (2018) Bacteria as biological control agents of freshwater cyanobacteria: is it feasible beyond the laboratory? Appl Microbiol Biotechnol 102:99119923. 
Nishu SD, Kang Y, Han I, Jung TY, Lee TK (2019) Nutritional status regulates algicidal activity of Aeromonas sp. L23 against cyanobacteria and green algae. PLoS ONE 14(3): e0213370.

Padisak J (1997) Cylindrospermopsisraciborskii (Woloszynska)SeenayaandSubba Raju, an expanding, highly adaptive cyanobacterium: worldwide distribution and review of ecology. Arch Hydrobiol107:563593.

Paerl HW, Otten TG (2013) Harmful cyanobacterial blooms: causes, consequences, and controls. Microb Ecol 65: 995-1010.

Rücker J, Stüken A, Nixdorf B, Fastner J, Chorus I, Wiedner C (2007) Concentrations of particulate and dissolved cylindrospermopsin in 21 Aphanizomenon-dominated temperate lakes. Toxicon 50:800-809.

Shao J, Li R, Lepo JE, Gu J-D (2013) Potential for control of harmful cyanobacterial blooms using biologically derived substances: problems and prospects. J Environ Manage 125:149-155.

Smith MJ, Shaw GR, Eaglesham GK, Ho L, Brookes JD (2008) Elucidating the factors influencing the biodegradation of cylindrospermopsin in drinking water sources. Environ Toxicol 23:413-421.

Svircev Z, Obradovic V, Codd GA, Marjanovic P, Spoof L, Drobac D (2016) Massive fish mortality and Cylindrospermopsis raciborskii bloom in Aleksandrovac Lake. Ecotoxicol 25:1353-1363.

Tsuji K, Asakawa MY, Anzai T, Sumino T, Harada KI (2006) Degradation of microcystins using immobilized microorganism isolated in an eutrophic lake. Chemosphere 65:117-124.

Van Apeldoorn ME, van Egmond HP, Speijers GJA, Bakker GJI (2007)Toxins of cyanobacteria. Mol Nutr Food Res 51: 7-60.

Van Wichelen J, Vanormelingen P, Codd GA, Vyverman W (2016) The common bloom-forming cyanobacterium Microcystis is prone to a wide array of microbial antagonists. Harmful Algae 55: 97111.

Weiss G, Kovalerchick D, Lieman-Hurwitz J, Murik O, De Philippis R, Carmeli S, Sukenik A, Kaplan A (2019) Increased algicidal activity of Aeromonas veronii in response to Microcystis aeruginosa: interspecies crosstalk and secondary metabolites synergism. Environ Microbiol 21:1140-1150.

Wilkens SL, Maas EW (2012) Development of a novel technique for axenic isolation and culture of Thraustochytrids from New Zealand marine environments. J Appl Microbiol 112: 346-352.

Wormer L, Cires A, Carrasco D, Quesada A (2008) Cylindrospermopsin is not degraded by co-occurring natural bacterial communities during a 40-day study. Harmful Algae 7: 206-213.

Wörmer L, Huerta-Fontela M, Cirés S, Carrasco D, Quesada A (2010) Natural photodegradation of the cyanobacterial toxins microcystin and cylindrospermopsin. Environ Sci Technol 44:3002-3007. 
Yang J, Qiao K, Lv J, Liu Q, Nan F, Xie S, Feng J (2020) Isolation and Identification of Two Algae-Lysing Bacteria against Microcystis aeruginosa. Water 12: 2485

Figures

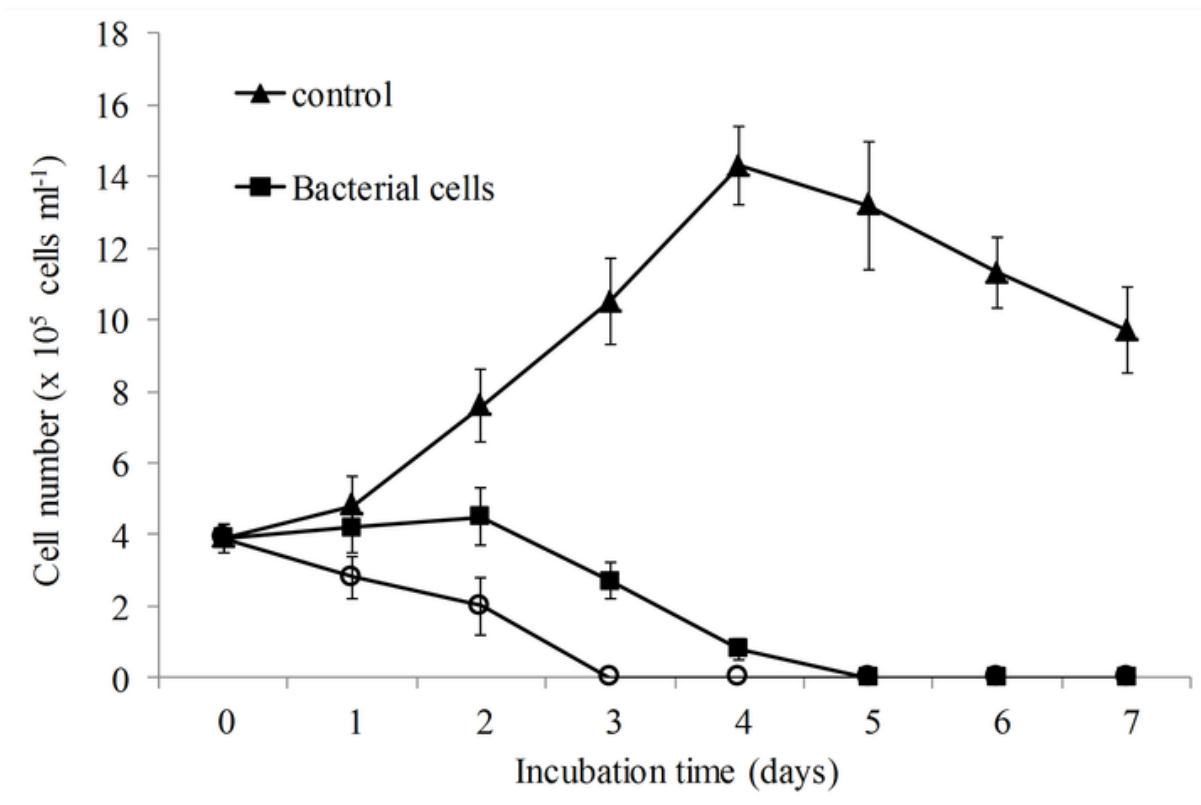

Fig.1

Figure 1 
Changes in the growth of C. raciborskii co-cultivated with living cells and filtrate of Bacillus flexus SSZ01.

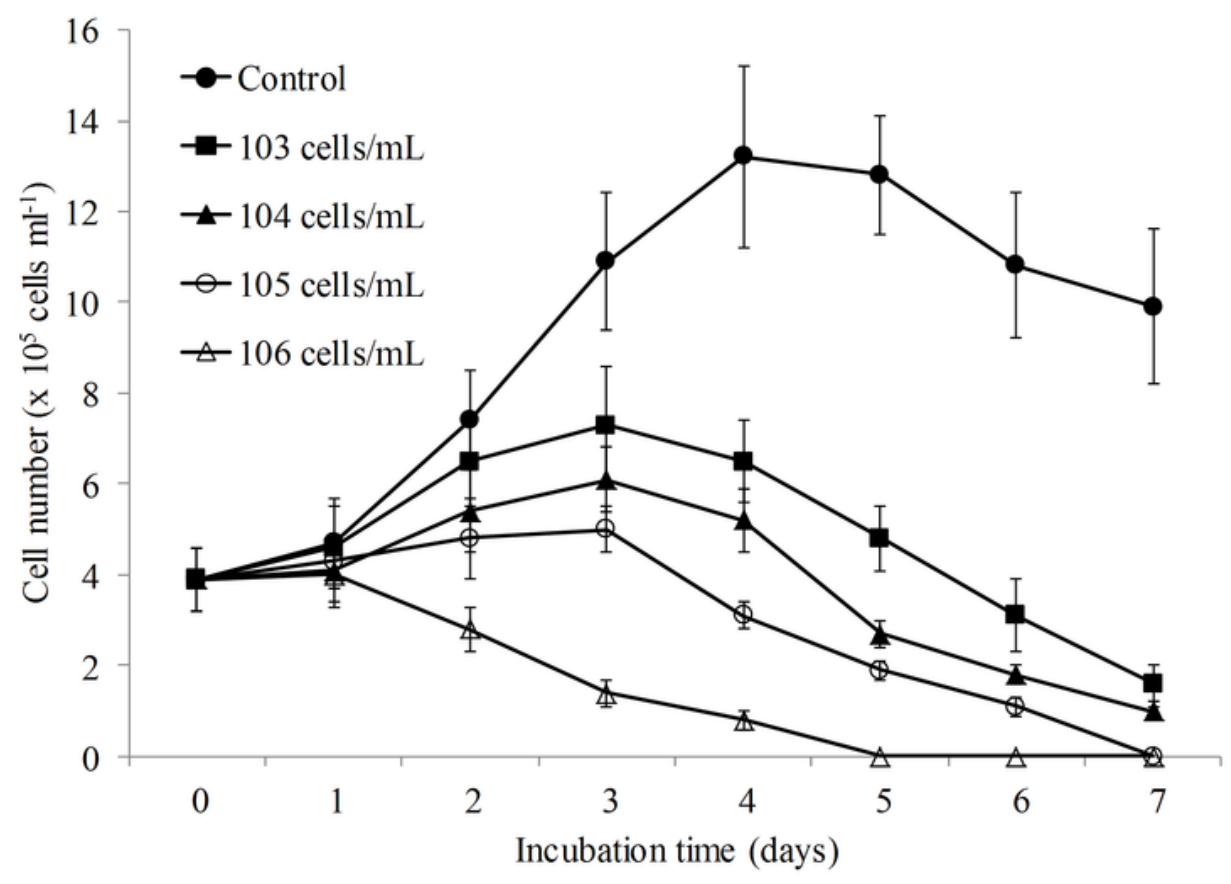

Fig. 2

Figure 2

Algicidal effects of different initial cell densities of SSZ01 on C. raciborskii 


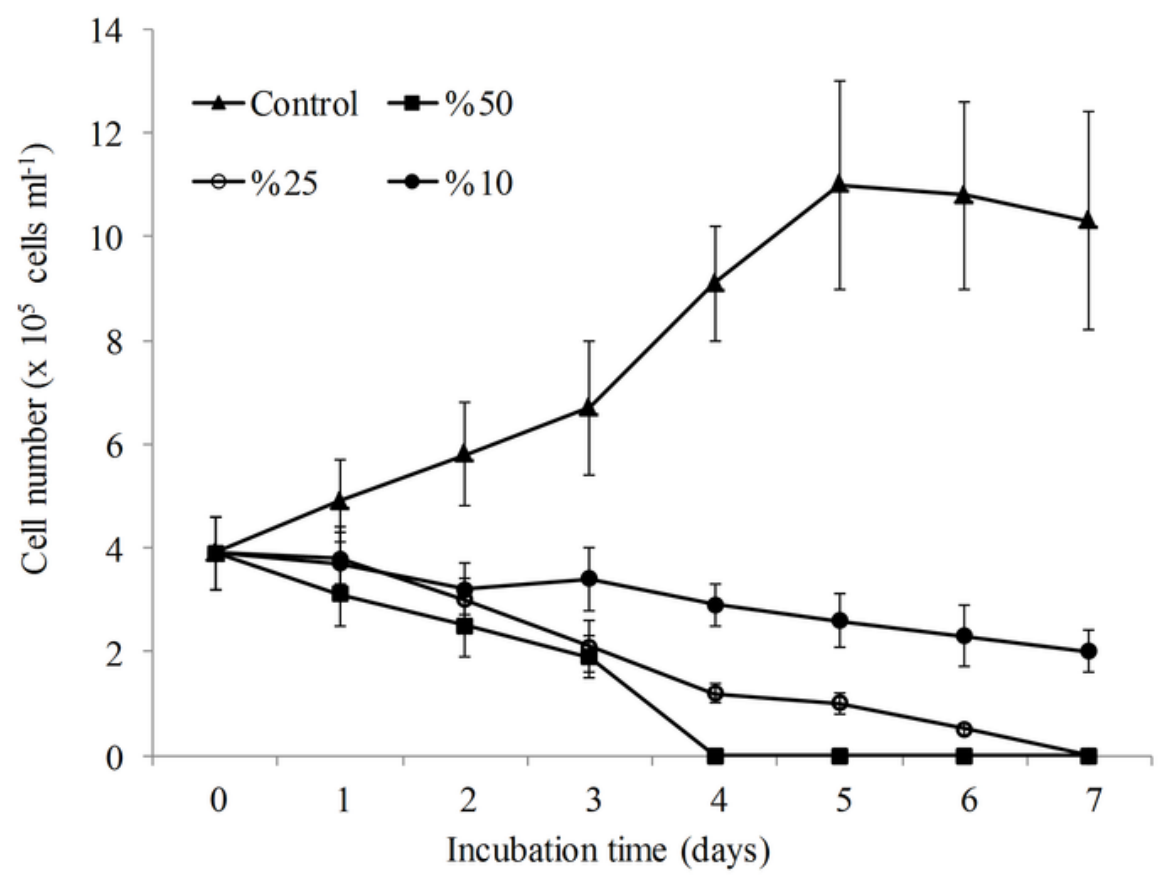

Fig.3

\section{Figure 3}

Algicidal effects of different filtrate proportions of SSZ01 on C. raciborskii 


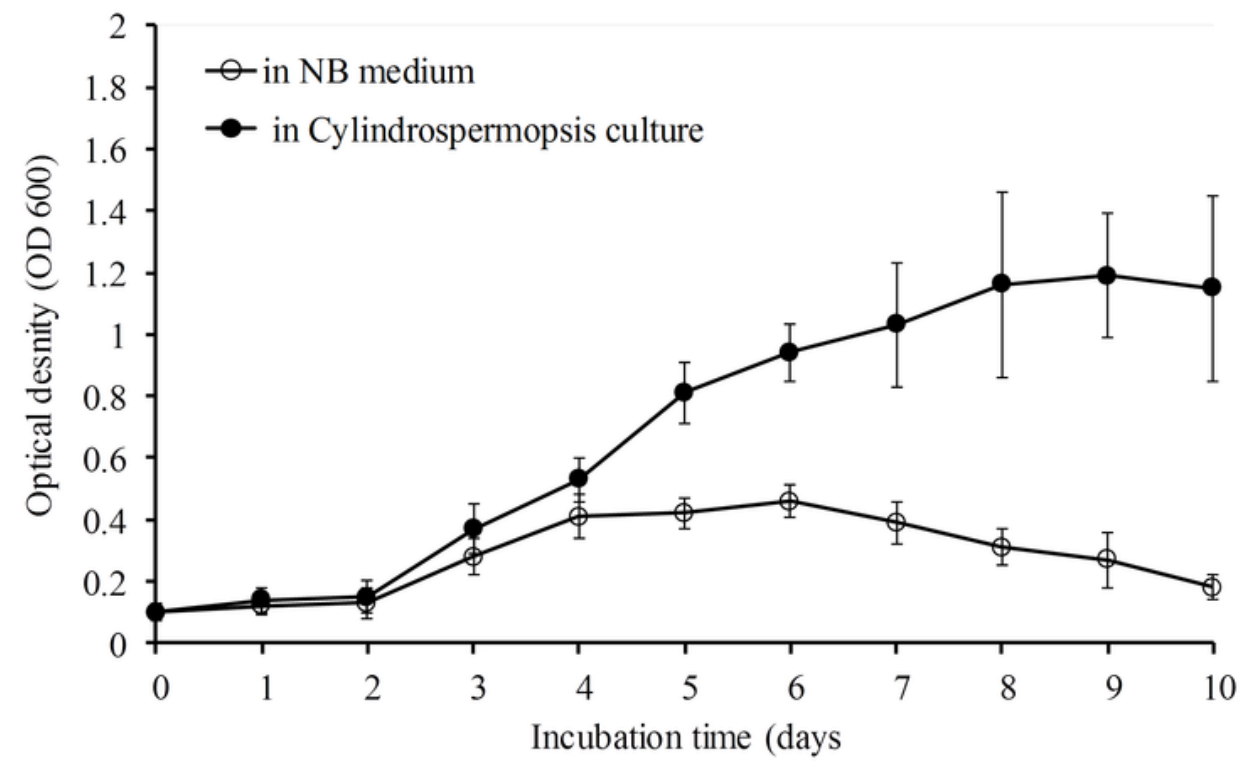

Fig. 4

\section{Figure 4}

Growth curve of SSZ01 (optical density) grown in NB medium and co-cultivated with living cells of C. raciborskii 


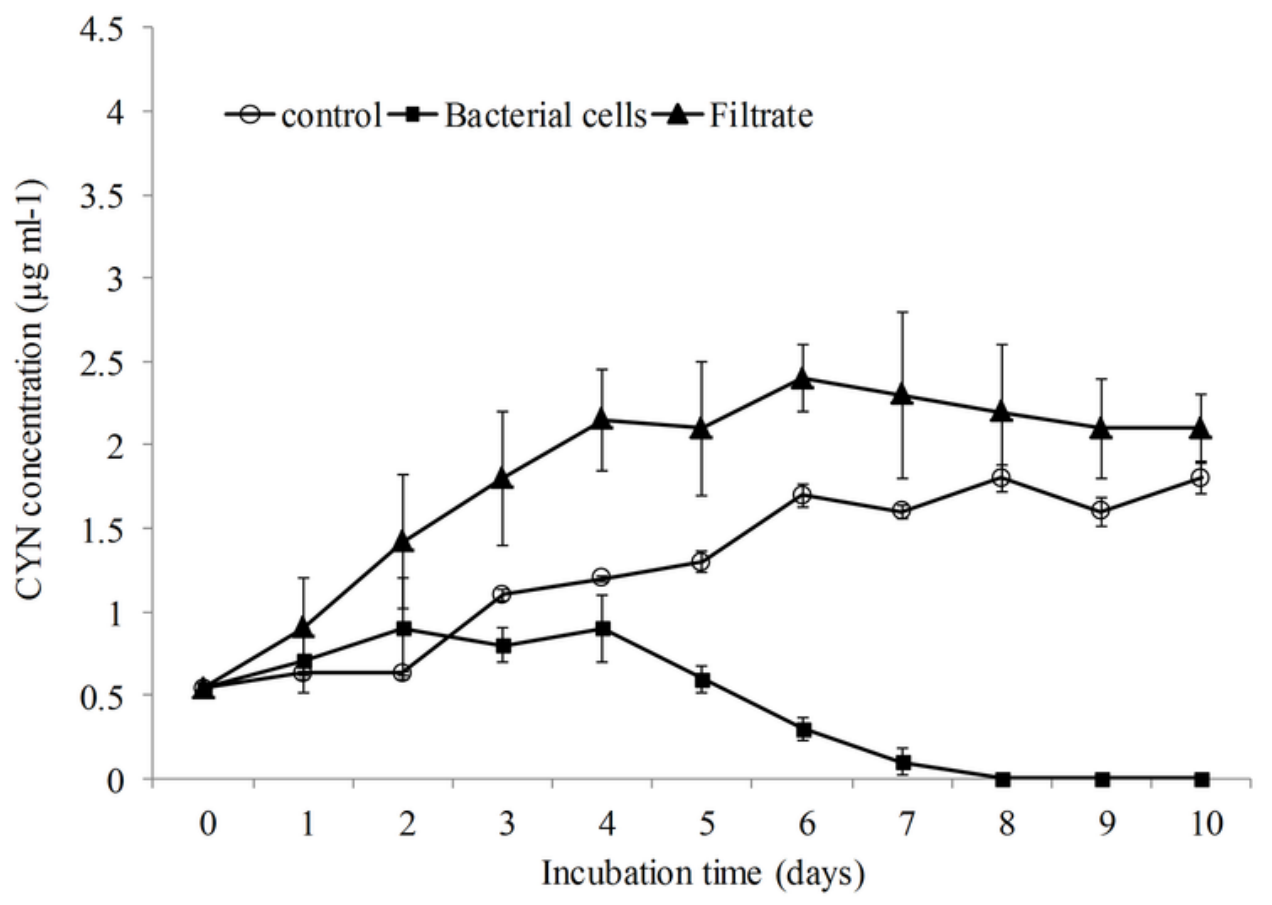

Fig.5

\section{Figure 5}

Changes in concentrations of cylindrospermopsin released into the medium of $\mathrm{C}$. raciborskii cultures during incubation with living cells and filtrate of SSZ01. 


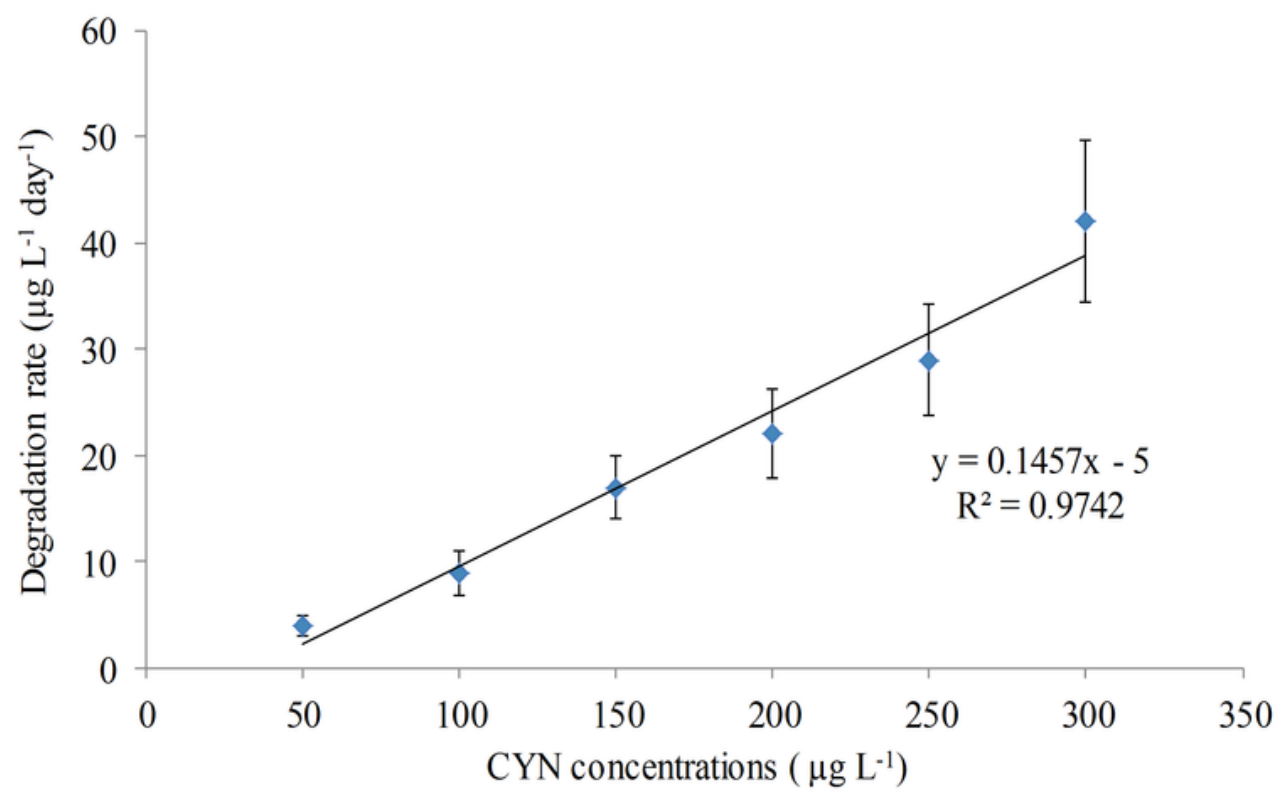

Fig.6

Figure 6

CYN biodegradation rate by SSZ01 at different initial CYN concentrations.

\section{Supplementary Files}

This is a list of supplementary files associated with this preprint. Click to download. 
- finalgraphabstract.jpg

Page 18/18 